\title{
Jornalismo em quadrinhos e relatos de guerra: considerações sobre a tradução de Le photographe
}

DOl: http://dx.doi.org/10.21165/el.v48i3.2342

\section{Sabrina Moura Aragão'}

\section{Resumo}

O presente trabalho busca explorar aspectos da tradução da história em quadrinhos francesa Le photographe, publicada entre 2003 e 2006, e traduzida no Brasil como O fotógrafo, entre 2006 e 2010. A obra se vale do uso de desenhos e fotografias na construção da narrativa e retrata a guerra entre União Soviética e Afeganistão na década de 1980. Interessa-nos observar de que forma a representação do Outro se constitui a partir da relação entre imagem e texto no contexto original, bem como no contexto da tradução. As imagens fotográficas em conjunção com o texto contribuem para a criação de representações culturais, haja vista o poder atribuído à fotografia jornalística de testemunhar o real. Percebemos, ainda, que o próprio ato de fotografar o estrangeiro e registrar o seu cotidiano em uma narrativa gráfica configura um ato de tradução cultural.

Palavras-chave: tradução; jornalismo em quadrinhos; representação cultural.

1 Universidade Federal de Santa Catarina (UFSC), Florianópolis, Santa Catarina, Brasil; sabrina.aragao@ufsc.br; https://orcid.org/0000-0002-9114-4899 


\section{Journalisme en bande dessinée et rapports de guerre: considérations sur la traduction de Le photographe}

\section{Résumé}

Ce travail a pour but de discuter des aspects de la traduction de la bande dessinée française Le photographe, publiée entre 2003 et 2006, et traduite au Brésil comme 0 fotógrafo, entre 2006 et 2010. L'oeuvre utilise des dessins et photographies dans la construction du récit et raconte la guerre entre l'Union Soviétique et l'Afghanistan dans les années 1980. On s'intéresse à observer de quelle façon la représentation de l'Autre se constitue à partir de la relation entre image et texte dans le contexte original, ainsi comme dans le contexte de traduction. Les images photographiques associées au texte contribuent pour la création de représentations culturelles, une fois qu'on attribue à la photographie le pouvoir de témoigner la réalité. On observe, encore, que l'acte de photographier l'étranger et enregistrer son quotidien dans une bande dessinée constitue lui-même, un acte de traduction culturelle.

Mots-clés: traduction; journalisme en bande dessinée; représentation culturelle.

\section{Introdução}

A linguagem jornalística, que narra fatos verídicos em um contexto histórico específico, cria representações culturais no processo de leitura. No caso da tradução, isso ocorre tanto no contexto de partida quanto no de chegada, o que pode criar novas representações, muitas vezes não previstas na língua/cultura de partida, haja vista que novos leitores, em novos contextos culturais, surgem no horizonte de leitura da obra em tradução.

Ao se pensar na função tradicionalmente atribuída à linguagem jornalística, que é o registro do real, observa-se que o uso de imagens, sobretudo fotográficas, atreladas às notícias, tornou-se uma prática comum ao longo da história do jornalismo impresso, assim, a foto passou a ser usada para corroborar o fato noticiado. Nesse sentido, vê-se que o uso de imagens fotográficas em conjunção com o texto contribui para a criação de representações culturais, haja vista o poder atribuído à fotografia jornalística de testemunhar o real.

Os estudos sobre as histórias em quadrinhos já revelaram o potencial representacional que essa forma de arte possui graças à conjunção entre imagem e texto. Além disso, por ser constituída por dois sistemas de signos distintos, dialoga, frequentemente, com outras linguagens, como o cinema e a literatura. Nesse sentido, este trabalho propõe uma análise da obra de jornalismo em quadrinhos Le photographe. Publicada na França em três volumes entre 2003 e 2006, e traduzida no Brasil como 0 fotógrafo, também em três partes, entre 2006 e 2010, a obra mescla a linguagem dos quadrinhos, por 
meio de desenhos compostos pelo quadrinista Emmanuel Guibert, com a linguagem jornalística, com as fotografias do fotojornalista Didier Levèfre. A relação estabelecida entre quadrinhos e jornalismo na obra pode ser observada não apenas no formato, mas também no tema, pois narra o trabalho da organização Médicos Sem Fronteiras durante a ocupação soviética no Afeganistão na década de 1980.

O próprio ato de fotografar o estrangeiro e registrar o seu cotidiano em uma narrativa gráfica configura um ato de tradução cultural com implicações para a criação de identidades culturais; nesse sentido, este trabalho se propõe a problematizar a construção de representações culturais a partir do relato de fatos reais, atentando-se para o processo de transformação engendrado pela tradução e pela relação entre imagem e texto característica das linguagens jornalística e quadrinística².

\section{Quadrinhos e jornalismo}

As histórias em quadrinhos, por sua natureza formal, exploram diversas formas de representação. O mestre dos quadrinhos, Will Eisner (1999), prevê esse potencial de diálogo entre diferentes mídias e os quadrinhos, e afirma ainda, em outra obra, que os quadrinhos são "uma forma de arte voltada para a emulação da experiência real" (EISNER, 1999, p. 91), o que denota uma aproximação ainda maior com a função dada pelo senso comum ao jornalismo: a de relatar o real. Sobre esse aspecto, comenta o sociólogo Érik Neveu (2005, p. 85): "A interrogação acerca do poder - presumivelmente excessivo - dos jornalistas é tão antiga quanto a própria imprensa".

No caso de Le photographe, a aproximação com a linguagem jornalística se dá tanto no aspecto formal, quanto no conteúdo. No que se refere aos aspectos formais, há o uso de fotografias jornalísticas que retratam a guerra no país, além da narrativa textual, que parte dos diários feitos pelo fotojornalista Didier Lefèvre, que fora contratado pela Médicos Sem Fronteiras para cobrir e registrar o trabalho da organização. Com relação ao conteúdo, trata-se de uma história em quadrinhos que narra fatos reais ocorridos em um contexto histórico determinado, fatos estes amplamente noticiados à época, além de apresentarem pessoas que testemunharam os acontecimentos ali representados, cujas histórias são contadas em forma de diálogos presentes nos balões.

Por fim, em ambas as mídias - jornal e quadrinhos - é possível observar a manipulação da imagem, em que há a "seleção dos elementos necessários à narração, a escolha da perspectiva a partir da qual se permitirá que o leitor os veja e a definição de cada símbolo ou elemento a ser incluído" (EISNER, 1999, p. 41). No próximo item veremos de forma mais detalhada como tais características se apresentam no contexto do jornalismo em quadrinhos.

2 As reflexões expostas no presente artigo derivam de minha tese de doutorado, intitulada o conhecimento do outro por meio da imagem e da tradução, defendida em 2018. 


\section{Jornalismo em quadrinhos}

Le photographe possui um cunho jornalístico, ao mesmo tempo que é, também, uma narrativa gráfica baseada nos registros do fotojornalista Didier Lefèvre. Segundo Ramos e Chinen (2016, p. 208), o jornalismo em quadrinhos, popularizado por Joe Sacco3, caracteriza-se por ser um estilo que se vale de elementos do fazer jornalístico que são apropriados pela linguagem dos quadrinhos. Assim, tais obras utilizam recursos estéticos e formais dos quadrinhos para relatar fatos a partir de testemunhos, depoimentos, entrevistas e viagens a países em guerra para compor uma reportagem narrada em quadrinhos. Ainda segundo o autor, obras de jornalismo em quadrinhos "têm se popularizado tanto pelo diferencial no modo como as reportagens são narradas quanto pela temática delas, voltada à intenção de dar voz às pessoas que vivem em regiões em conflito" (RAMOS; CHINEN, 2016, p. 198).

No que concerne à linguagem jornalística, Buitoni (2012) afırma que a presença de imagens em jornais é uma necessidade natural, uma vez que, segundo a autora, o homem sempre se valeu de representações visuais para contar histórias, sejam elas reais ou imaginadas. Tais imagens já existiam na imprensa, antes mesmo da invenção da fotografia, por meio do trabalho de ilustradores, que iam até os locais dos acontecimentos e reproduziam cenas da vida política, crimes, paisagens, catástrofes e retratos da maneira mais fiel possível (BUITONI, 2012). A autora defende que a fotografia jornalística possui um "embrião narrativo", que se manifesta "quando a imagem nos dá pistas de uma ação a ser continuada, ou que pelo menos nos sugira a existência de ações - antes ou depois - da cena registrada" (BUITONI, 2012, p. 150).

A reflexão de Buitoni (2012) nos permite afirmar que a potencialidade narrativa das fotografias jornalísticas torna a concepção de Le photographe, isto é, a criação de uma narrativa em quadrinhos a partir de fotos documentais, algo natural. Guibert (2009) comenta sobre o potencial narrativo das fotos no prefácio do livro Conversations avec le photographe ao ver, pela primeira vez, uma folha de contato ${ }^{4}$ contendo os negativos das imagens tiradas por Lefèvre durante sua estadia no Afeganistão com os Médicos Sem Fronteiras. $\mathrm{O}$ artista destaca a semelhança dessas folhas com a linguagem das histórias em quadrinhos, o que mostra a gênese da ideia de concepção de Le photographe, já que a folha de contato, assim como uma página de HQ, contém "quadros, alinhados, nos

3 Quadrinista e jornalista maltês radicado nos Estados Unidos, Sacco é autor das premiadas obras Palestina, publicada originalmente entre 1993 e 1995, e Notas sobre Gaza, de 2009. Ambas as obras foram publicadas no Brasil pelas editoras Conrad e Quadrinhos na Cia., respectivamente.

4 Segundo artigo da revista de fotografia Zum, a folha de contato serve como registro do que foi fotografado e constituía uma ferramenta fundamental do fotojornalismo antes do advento da fotografia digital no processo de edição. "A folha de contato, criada mediante a impressão direta de um rolo ou sequência de negativos, permite ao fotógrafo a primeira visão daquilo que ele ou ela capturou no filme, mas também propicia uma visão do seu processo criativo" (AVELLAR, 2015). 
quais uma ação se desenvolve [...] Nunca ninguém havia me contado o que quer que fosse dessa forma. E a história era realmente instigante"5 (GUIBERT, 2009, p. 15, tradução nossa).

No próximo item, discutiremos a questão da imagem e seu potencial narrativo, sobretudo quando associada ao texto, constituindo o meio de expressão da linguagem dos quadrinhos.

\section{A fotografia de guerra como linguagem}

Segundo Baeza Gallur (2003, p. 35-36, tradução nossa), a fotografia de imprensa, ou seja, "imagens que a imprensa planifica e produz ou compra e publica como conteúdo próprio"6, divide-se em dois tipos: fotojornalismo e fotoilustração. O primeiro é influenciado pelo documentarismo, que, de acordo com o autor, consiste em outro grande campo da "fotografia de realidade", atendendo mais a fenômenos estruturais do que à conjuntura de notícias; além disso, possui um propósito definido por uma encomenda ou pelo desejo de difusão midiática. No segundo tipo, a fotografia cumpre a função de ilustração, isto é, tem como finalidade tornar mais compreensível um fato ou ideia por meio da representação mimética e depende de um texto prévio que marca e contextualiza a imagem, que, por sua vez, deve explicar o texto, torná-lo mais claro ou despertar, no destinatário, o interesse pelos conteúdos do texto (BAEZA GALLUR, 2003).

Em outro trecho do livro, Baeza Gallur (2003) elabora uma nova tipologia ao comentar as fotos que não são exatamente imagens de imprensa, isto é, que não são dirigidas especificamente à publicação em jornais diários, mas antes em galerias, ou publicadas em forma de livro. $\mathrm{O}$ autor as denomina fotografias documentais, que tratam de temas estruturais e são fruto de um trabalho que conta com maior tempo e reflexão se comparado às imagens publicadas em periódicos, que dependem das diretrizes de um meio da imprensa sobre temas mais conjunturais e vinculados a valores de informação e notícia (BAEZA GALLUR, 2003). Assim, de acordo com as classificações de Baeza Gallur (2003), as imagens presentes em Le photographe seriam fotografias documentais, haja vista que são o resultado de um trabalho de vários meses e contaram com um projeto de edição e diagramação, além de não estarem vinculadas a um conjunto de notícias encargadas por um jornal específico. Baeza Gallur (2003) estabelece uma relação entre a fotografia documental e a arte, uma vez que nesse tipo de imagem a questão da autoria está fortemente presente, seja por meio da relevância do fotógrafo no cenário da fotografia, seja no que se refere ao desenvolvimento de uma linguagem que se abre para

5 No original: "des cases, alignées, où une action se déroule [...] Jamais personne ne m'avait raconté quoi que ce soit de cette manière. Et le récit était vraiment palpitant".

6 No original: "imágenes que planifica y produce o compra y publica la prensa como contenido própio" 
a subjetividade. 0 fato de tais fotos serem expostas em galerias também as aproxima mais do mundo da arte do que do mundo dos jornais. Sontag (2003, p. 100-101) também reflete a esse respeito quando afirma que "a visita a um museu ou uma galeria é uma situação social, crivada de distrações, no curso da qual a arte é vista e comentada. Em certa medida, o peso e a seriedade de tais fotos sobrevivem melhor em um livro". A nosso ver, o comentário de Sontag (2003) põe em relevo a perenidade do livro em relação à intermitência das exposições; assim, a foto sobrevive melhor em um álbum como Le photographe, que contém fotos tiradas há mais de 30 anos, do que se fosse depender de uma exposição, sobretudo no Brasil, onde o trabalho de Didier Lefèvre não é tão conhecido como o de alguns fotógrafos nacionais, como Sebastião Salgado ou Araquém Alcântara.

No que se refereà relação entre fotografia jornalística, realidade e narrativa gráfıca presente em Le photographe, é possível afirmar que as fotos estabelecem um compromisso com a verdade, ou seja, retratam cenas reais e pessoas reais. De acordo com Sontag (2003), que discorre sobre as fotografias tiradas durante a Guerra Civil Espanhola, tais imagens possuem dois atributos contraditórios, pois gozam da credencial de objetividade, mas partem, forçosamente, de um ponto de vista: "[as fotos] eram um registro do real incontroverso como nenhum relato verbal poderia ser, por mais imparcial que fosse -, uma vez que a máquina fazia o registro. E as fotos davam testemunho do real - uma vez que alguém havia estado lá para tirá-las." (SONTAG, 2003, p. 26).

Kossoy (2009, p. 19) amplia tal discussão ao afırmar que, além de ser, historicamente, "aceita e utilizada como prova definitiva, 'testemunho da verdade"', a fotografia possui uma realidade própria, isto é, uma segunda realidade constituída na sua diegese:

A fotografia tem uma realidade própria que não corresponde necessariamente à realidade que envolveu o assunto, objeto do registro, no contexto da vida passada. Trata-se da realidade do documento, da representação: uma segunda realidade, construída, codificada, sedutora em sua montagem, em sua estética, de forma alguma ingênua, inocente, mas que é, todavia, o elo material do tempo e espaço representado, pista decisiva para desvendarmos o passado. (KOSSOY, 2009, p. 22, grifos do autor).

Depreende-se que a foto, enquanto documento, passa a ser um objeto que, por um lado, representa, ou seja, não reproduz o real. Por outro lado, quando o autor se vale da noção de segunda realidade, pressupõe-se que existe uma primeira. O autor afirma que essa primeira realidade, que se relaciona com a realidade interior da imagem, é inacessível fotograficamente; trata-se da história abrangente e complexa daquilo que é retratado (KOSSOY, 2009). Paralelamente, Chartier (1991) reflete sobre a representação, não apenas fotográfica, mas na pintura e na escultura, e chama a atenção para o fato de a representação estabelecer uma relação entre uma imagem presente e um objeto ausente (CHARTIER, 1991). Ambos os autores, Kossoy (2009), ao falar sobre o 
inacessível da fotografia, e Chartier (1991), ao mencionar a ausência do objeto, afirmam que a representação, apesar de não ser o próprio objeto, é capaz de trazer esse objeto para o receptor por meio de uma analogia. Em outras palavras, é possível afırmar que a representação torna o objeto ausente presente por meio da linguagem. Koch (2004) partilha dessa visão ao considerar a referenciação, o que compreendemos como o ato de referir-se a um objeto ausente por meio da representação, uma atividade discursiva em que o sujeito age sobre o discurso e constrói o mundo.

Assim como Sontag (2003), Kossoy (2009, p. 31, grifos do autor) também reconhece a ambivalência da fotografia que, ao mesmo tempo em que funciona como documento do real, como fonte histórica, não deve ser entendida "independentemente do processo de construção da representação em que se originou. A materialização da imagem ocorre enquanto etapa final e produto de um complexo processo de criação técnico, estético, cultural elaborado pelo fotógrafo". Assim, para o estudioso, a foto é sempre um documento/ representação. Em relação a tais aspectos, Sontag (2003, p. 41-42, grifo da autora) discorre sobre o fato de a fotografia poder ser usada como prova, ao contrário de uma pintura como as feitas por Goya, da série Los desastres de la guerra, que retratam as atrocidades cometidas pelas tropas de Napoleão na Espanha em 1808:

\begin{abstract}
A linguagem comum estabelece a diferença entre imagens feitas à mão, como as de Goya, e fotos, mediante a convenção de que artistas "fazem" desenhos e pinturas, ao passo que fotógrafos "tiram" fotos [...]. As imagens de Goya são uma síntese. Garantem: coisas assim aconteceram. Em contraste, uma só foto ou diafilme garante representar exatamente o que estava diante da lente da câmera. Não se espera que uma foto evoque, mas sim que mostre. Por isso as fotos, ao contrário das imagens feitas à mão, podem servir como provas.
\end{abstract}

Nossa opinião é a de que tanto o desenho quanto a fotografia, por mais que representem ou reproduzam cenas reais, partem de um ponto de vista; logo, ambos refletem tendências e posições ideológicas imbuídas de valores e preconceitos. 0 desenho pode ser hiper-realista e a fotografia pode ser objetiva, sem retoques, mas o ato de fotografar, apesar de ser mecânico e resultar em um material derivado de processos eletrônicos e/ ou químicos, precisa de um sujeito para realizá-lo. Quando se vê a imagem de um conflito, de catástrofes, ou da miséria alheia, é preciso se perguntar sobre os limites da objetiva, ou seja, imaginar o que há ao redor daquela imagem, o seu entorno. Essa realidade não é acessível a quem vê a fotografia, é parte de uma realidade e, como não existem meias realidades, a foto não é capaz de registrar o real, mas de mostrar algo que pode ser real.

\title{
Tradução e representação cultural
}

Conforme apontado no item anterior, diversos teóricos e críticos da fotografia reconhecem que esse sistema de signo encerra uma ambivalência: a foto possui uma realidade 
interna, que se manifesta enquanto linguagem, contudo, essa realidade não é acessível a quem vê a fotografia, é parte de uma realidade, que tem o potencial de ser verdadeira. Nesse contexto, poderíamos pensar na questão da ambivalência enquanto um elemento constituinte do processo de representação pela linguagem, uma vez que a representação é sempre parcial e pressupõe a participação do sujeito, tanto aquele que produz quanto aquele que interpreta a mensagem por meio da linguagem. No caso de Le photographe e sua tradução brasileira, a mensagem se constrói pelas imagens (fotos e desenhos) e pela língua (francês no original e português na tradução). Dessa forma, há pelo menos dois contextos distintos que influenciam a percepção - e a consequente construção da identidade do Outro - por meio da fotografia posta em relação com o texto.

No contexto da tradução cultural, também é possível reconhecer a ambivalência do sujeito, uma vez que a diferença se dá a partir da relação que o Eu estabelece com o Outro (BHABHA, 2006). Nesse sentido, a diferença cultural não está no ato em si, mas no locus do Outro, que é quem sugere que o objeto de identificação é ambivalente e é constituído em um processo de significação, deslocamento ou projeção; há, portanto, um julgamento cultural que constrói o significado a partir da interpretação, em suma, a representação do Outro. Bhabha (2006) não fala explicitamente da tradução interlingual, como é o caso que analisamos aqui, entre as versões francesa e brasileira da história em quadrinhos Le photographe; o autor fala de tradução em um sentido amplo, que podemos interpretar como a tradução da cultura do Outro em imagens (ora desenhos, ora fotografias) e também na interligação que essas imagens estabelecem com o texto. Bhabha (2013) fala da tradução como uma forma de negociação fronteiriça que se dá no local da diferença cultural. Entendemos que essa negociação, enquanto tradução cultural, visa entender a diferença; nesse processo, a tradução transforma o Outro, pois ele passa a ser visto - ou traduzido - a partir da perspectiva do Eu.

Em Le photographe haveria, assim, um primeiro ato tradutório, no original, entre franceses e afegãos, e um segundo, entre o francês e o português do Brasil. É preciso ressaltar que, como dissemos acima, ao usar o termo tradução cultural, Bhabha (2013) pensa no processo de tradução como um fenômeno amplo, não se limitando à relação de textos em diferentes línguas. Segundo Pym (2010), o conceito de tradução cultural surgiu na Antropologia Social, que vê a descrição de culturas estrangeiras como formas de tradução. Ainda segundo o autor, após os trabalhos de Bhabha (2013), a noção de tradução cultural tem sido associada a movimentos materiais, à posição do tradutor, ao hibridismo cultural e ao cruzamento de fronteiras (PYM, 2010). Assim como Pym (2010), enxergamos a tradução como um produto que resulta da movimentação interlínguas; contudo, as reflexões de Bhabha (2013), apesar de considerarem a tradução em um sentido metafórico, em que todos os textos constituiriam traduções, são importantes, nas palavras do próprio Pym (2010), na medida em que trazem uma dimensão humana para o processo tradutório, enxergam a tradução mais como um processo cultural do que como um produto textual, evidenciam a questão do hibridismo cultural, desfazem muitas das oposições binárias de teorias da tradução precedentes e relacionam a tradução a movimentos demográficos 
que estão transformando as culturas. Em resumo, não consideramos que todos os textos sejam traduções; porém, é inegável que a tradução provoque questionamentos que vão além do produto textual que ela representa; ela constrói, reconstrói e desconstrói fronteiras culturais. O tradutor está em um entre-lugar, nos limites das culturas, em suma, em uma posição híbrida, onde ocupa o local entre duas línguas e culturas.

É nesse contexto que podemos pensar em mais uma manifestação da noção de ambivalência, dessa vez, na figura do tradutor, uma vez que o tradutor é um leitor que interpreta a obra e, por esse motivo, coloca suas impressões sobre ela na tradução (VENUTI, 1998). A tradução, como qualquer outra atividade cultural - a isto se inclui a fotografia, o desenho, etc. - produz e veicula valores. Por meio das escolhas de ângulo (na fotografia) e discursivas (no texto), fotógrafos, escritores e tradutores deixam pistas de suas próprias visões que, por sua vez, são interpretadas, aceitas, rebatidas, em suma, constantemente transformadas, pelo público.

A fim de verificarmos como tais questões se apresentam na obra, consideremos uma sequência retirada de Le photographe e a sua respectiva tradução para o português: 

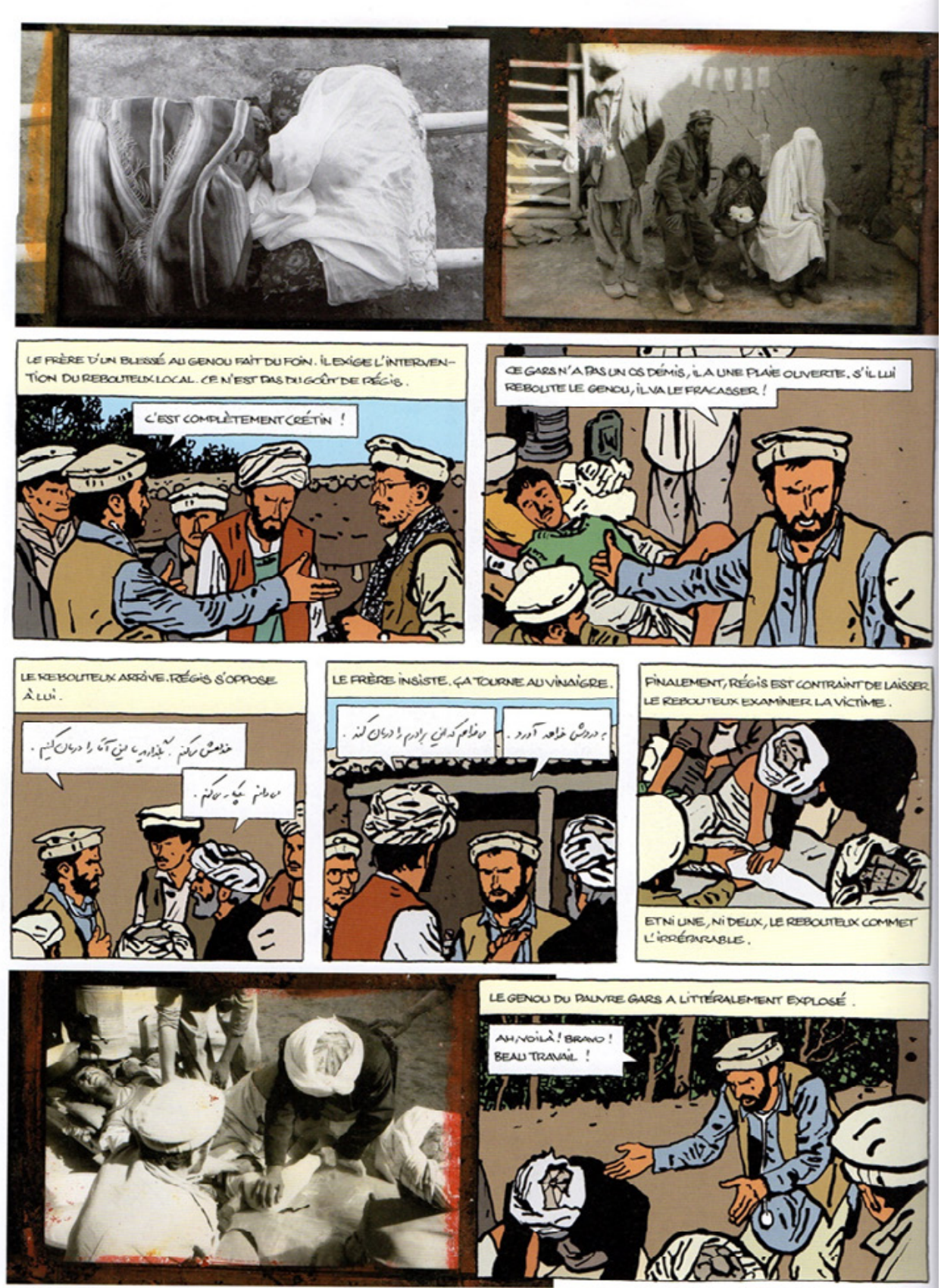

60

Figura 1. Le photographe

Fonte: Vol. 3, p. 60 
A sequência apresentada na Figura 1 mostra um conflito entre a cultura local afegã e a cultura ocidental dos médicos. Lefèvre narra, na legenda do primeiro quadrinho da segunda fileira, que um dos familiares de um ferido, que aparece em uma maca com o rosto coberto na primeira foto da página, exige a intervenção de um "rebouteux", o que contraria o médico Régis. Em francês, essa palavra deriva do verbo "rebouter", que significa realocar um membro deslocado ou fraturado. A pessoa que faz tal prática geralmente não é um médico, por essa razão, a atividade realizada pelos "rebouteux" é considerada polêmica na França, pois não há uma formação reconhecida por órgãos reguladores e o "rebouteux" exerce a prática devido a um dom. Régis explica, nos balões, que a intervenção do "rebouteux" é "estúpida" ("c'est complètement crétin"), pois o paciente possui uma ferida aberta no joelho, não um deslocamento ou fratura; assim, o médico francês diz que se o "rebouteux" intervier, ele vai acabar quebrando o joelho do enfermo. $\mathrm{Na}$ fileira seguinte, os diálogos entre o médico francês e o "rebouteux", no primeiro quadrinho, e entre o irmão da vítima e Régis são representados pela escrita em persa. Por meio da narração de Lefèvre, o leitor é capaz de compreender que os homens não chegam a um acordo e que discutem veementemente ("ça tourne au vinaigre"). No último quadrinho, que mostra o desenho do "rebouteux" tocando o joelho de ferido com a perna esticada, o fotógrafo diz, no texto da legenda, que Régis acaba cedendo e que acontece "o irreparável" ("I'irréparable"). O uso do "irréparable" deixa a narrativa em suspense, e a sequência é completada nos quadrinhos seguintes, com a fotografia do homem sendo tocado pelo "rebouteux", agora, com a perna dobrada; assim, o "irreparável" só é esclarecido no último quadrinho da página, quando Lefèvre relata, por meio da legenda, que o joelho do paciente "literalmente explodiu"; em seguida, o balão mostra a fala irônica do médico: "Bravo! Beau travail" [Parabéns! Belo trabalho!].

A Figura 1 expõe um episódio de choque de saberes locais e tradicionais e saberes ocidentais. A prática da medicina e a relação com os doentes é culturalmente marcada, e o relato de Lefèvre mostra com o que os Médicos Sem Fronteiras têm de lidar, ou seja, não só os doentes, mas suas famílias e costumes arraigados, como se vê em outros trechos da obra, que mostram como os médicos devem se portar com as mulheres, por exemplo. A posição de Régis é de ser contrário à intervenção do "rebouteux", usando argumentos médicos; contudo, ele não impede a ação do homem, o que demonstra que, mesmo contrariado, ele respeita a vontade do Outro e a cultura local. Trata-se de uma posição ambígua, pois é como se o médico ocidental não pudesse ser completamente médico, não como ele seria em seu contexto de origem, pois ele deve se adaptar ao seu público para poder trabalhar e para que os aldeões aceitem ser tratados por ele; por esse motivo ele se sujeita, em outros excertos da série, a auscultar mulheres por cima da roupa e aceita que o "rebouteux" interfira, mesmo que, nas duas circunstâncias, ele tenha seu trabalho médico prejudicado de alguma forma. Contudo, essa aceitação da cultura do Outro não é isenta de juízos de valor, como pudemos ver nas falas dos diálogos.

A seguir podemos observar como esse trecho foi traduzido: 


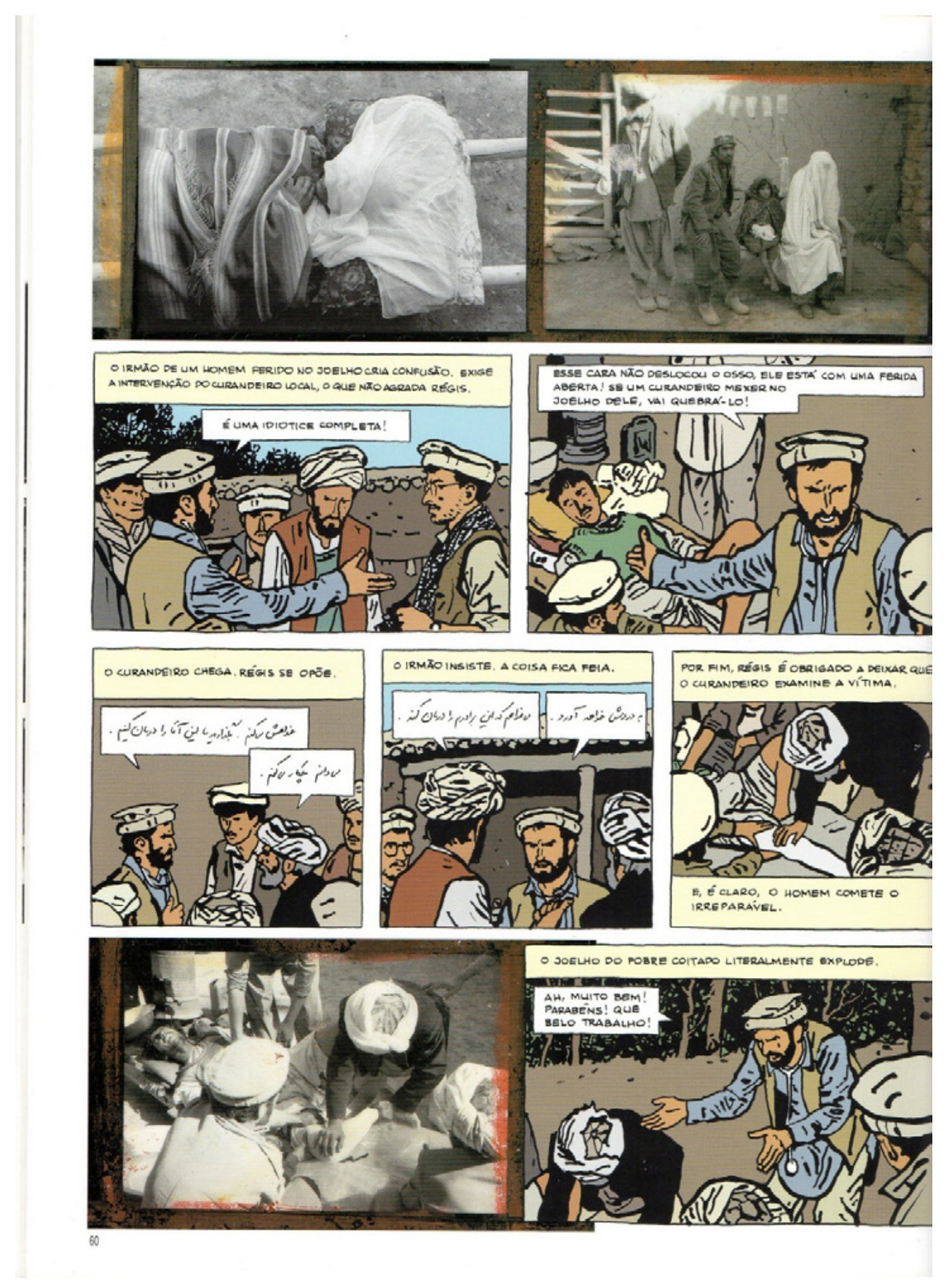

Figura 2. O fotógrafo

Fonte: Vol. 3, p. 60 
A Figura 2 mostra que a palavra francesa "rebouteux" foi traduzida como "curandeiro" no primeiro quadrinho da segunda fileira. Como explicamos anteriormente, "rebouteux" se refere a uma pessoa que pratica a realocação de membros fraturados ou deslocados e que não possui formação médica, valendo-se de métodos empíricos para curar contusões. Por outro lado, "curandeiro" em português refere-se a uma pessoa que trata doenças por meio de magia ou orações. Nesse sentido, a versão traduzida pode induzir a um erro de interpretação, pois um "rebouteux" não cura por meio da magia, mas por meio de movimentos que colocam os ossos deslocados no lugar. Além disso, a figura do "curandeiro", na tradução, contradiz os preceitos da religião muçulmana, praticada por grande parte da população afegã. Em português, a palavra "curandeiro" não remete à prática de recolocar ossos no lugar, de modo que a explicação de Régis, no segundo quadrinho da segunda fileira, onde o médico explica que o paciente tem uma ferida aberta e não uma fratura no osso, não faz sentido para o leitor brasileiro, uma vez que "curandeiro" não designa um sujeito que realiza um procedimento empírico de cura por meio de determinados movimentos. Porém, a tradução do verbo "rebouter" ("s'il reboute"), presente no original, por "mexer", na tradução, resolve parcialmente o problema porque o leitor vê, na imagem, que o homem toca na perna do ferido. O verbo "mexer" indica colocar em movimento, o que o "rebouteux" realmente faz, e é possível ver essa ação realizada na sequência narrativa: do desenho do terceiro quadrinho da segunda fileira, que mostra o paciente com a perna esticada, para a primeira foto da última fileira, que mostra o homem com a perna dobrada.

Ao se usar a palavra "curandeiro", é possível pensar que o homem faz algum tipo de oração ao tocar no doente, e que o ato de "mexer" no joelho seria algum tipo de ritual necessário para a cura. Tudo isso cria uma identidade cultural acerca do Outro que não corresponde à realidade, pois o homem não executa um procedimento espiritual, como faria um "curandeiro", mesmo que um "rebouteux" seja uma pessoa dotada de um dom, ele executa o procedimento por meio de movimentos nas articulações, e não por meios sobrenaturais. Em português, não há um referente específico para a palavra "rebouteux", talvez o que mais se aproxime seja "massagista" ou "quiroprático", mas este último designa uma profissão que exige formação específica na área, sendo regulamentado por órgãos como a Organização Mundial de Saúde (OMS), o que não ocorre com um "rebouteux", que não possui uma formação reconhecida institucionalmente. O uso de "curandeiro", a nosso ver, representa um caso de adaptação, pois no português do Brasil, esse referente remete à espiritualidade e não à prática de cura de luxações.

A seguir, consideremos mais um exemplo: 


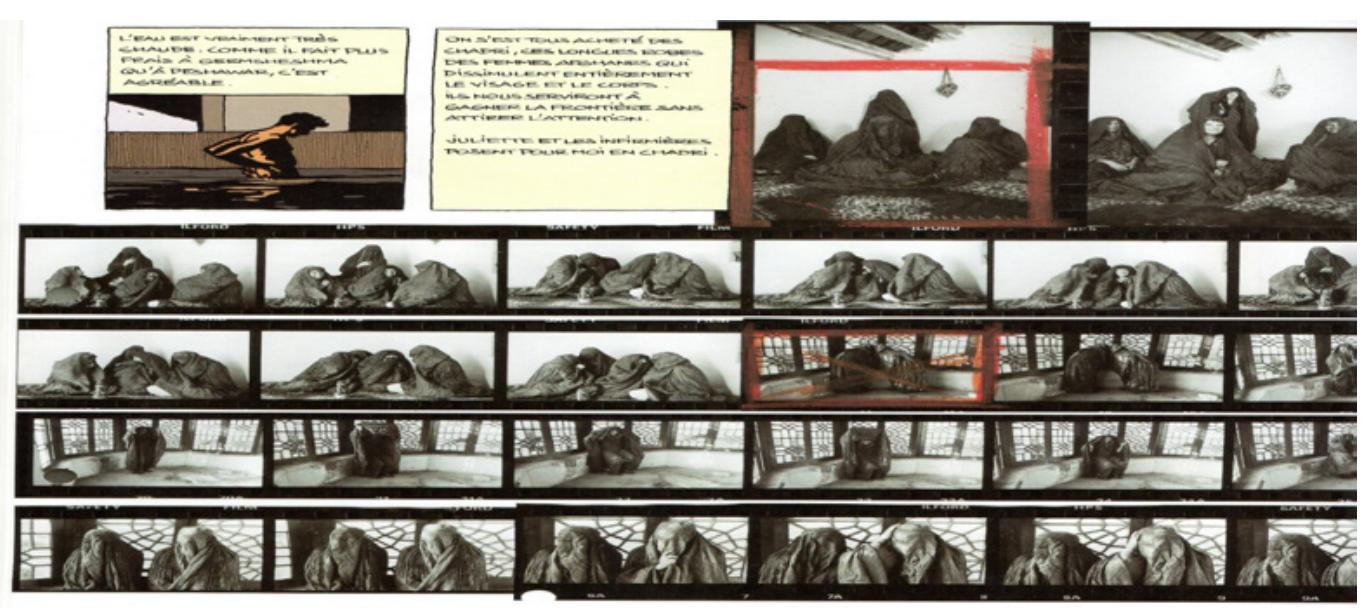

Figura 3. Le photographe

Fonte: Vol. 1, p. 34

Na sequência de imagens acima, Lefèvre fotografa as mulheres da equipe de Médicos Sem Fronteiras usando vestimentas afegãs. Por se tratar de roupas diferentes daquelas usadas pelas mulheres ocidentais, tanto francesas quanto brasileiras, isto é, por haver uma relação de contraste entre sistemas culturais, é possível perceber que é a relação entre a sequência de fotos e o nome da vestimenta "chadri" na legenda, tenta definir e explicar esse elemento "estranho" no contexto linguístico e cultural francês: "ces longues robes des femmes afghanes". A utilização da palavra francesa "robes" ("vestimentas" ou "vestidos", em português), atribui um nome ao referente para entendê-lo do ponto de vista da cultura dos leitores francófonos. Segundo o dicionário Trésor de la langue française, "robe" é um substantivo feminino que designa uma peça de roupa genérica de comprimento amplo, que pode ser usada por homens e mulheres. O "chadri" não é uma vestimenta no sentido genérico de "robe", pois somente as mulheres o usam e, diferentemente de qualquer peça de roupa usada no ocidente, ele cobre o rosto. O uso do "chadri" também representa uma prática cultural baseada em preceitos religiosos, pois ao cobrir o corpo, a mulher demonstra recato. Nesse sentido, o uso da palavra "robes" pelo narrador busca dar conta do sentido da vestimenta afegã de uma forma genérica, pois o narrador tenta explicar o que seria essa peça de roupa a partir de um referente de sua própria cultura, valendo-se da aparência da peça representada na fotografia.

Aqui, poderíamos pensar na noção de tradução cultural desenvolvida por Bhabha (2013), pois o narrador, ao nomear um elemento da cultura estrangeira a partir de seus próprios saberes e referentes culturais, transforma a cultura do outro ao tentar explicá-la, ao tentar trazê-la para perto de si. Além disso, o uso do "chadri" pela equipe é desnaturalizado de seu contexto cultural afegão, pois não veste, nem demonstra decoro, mas disfarça. Lefèvre relata que toda a equipe, incluindo os homens, usará essa peça para passar pela fronteira sem chamar atenção. Esse uso desnaturalizado evoca o que Bhabha (2013) 
chama de blasfêmia, não no sentido de "uma representação deturpada do sagrado pelo secular" (BHABHA, 2013, p. 355), apesar de o uso do "chadri" corresponder a uma prática baseada em preceitos religiosos, mas a blasfêmia como resultado de um "ato transgressor de tradução cultural" (BHABHA, 2013, p. 356). Em outras palavras, ao tentar explicar a cultura do outro, o narrador transforma essa cultura, pois ele parte de seus próprios referentes para nomeá-la; assim, o uso da palavra "robes" para designar "chadri" acaba transformando o elemento cultural estrangeiro.

Vejamos agora a tradução dessa sequência em português:

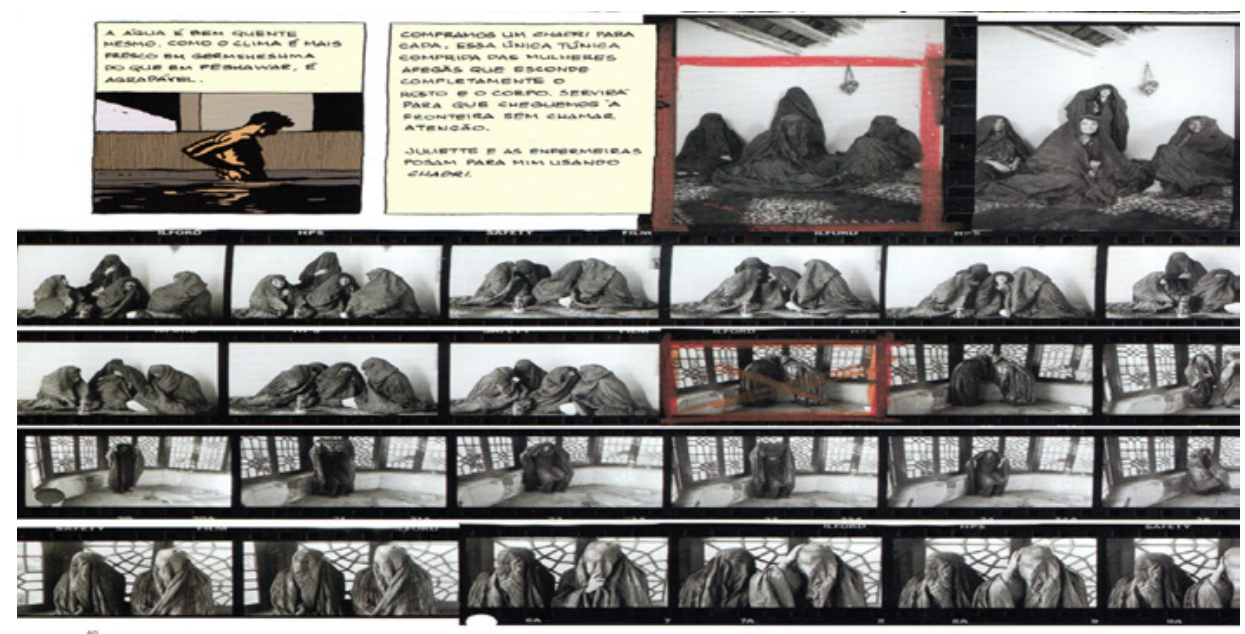

Figura 4. O fotógrafo

Fonte: Vol. 1, p. 40

Ao verificarmos a tradução, nota-se que a palavra "chadri" é transcrita em itálico na tradução, assim, a palavra de origem estrangeira é evidenciada tipograficamente, o que não ocorre no texto de partida. Vale ressaltar que, após os atentados de 11 de setembro de 2001, o Afeganistão volta a ocupar os noticiários ocidentais e é justamente nessa época que é publicado o primeiro volume da série na França e, três anos depois, no Brasil. Chamamos atenção para esse fato porque era comum a referência a essa vestimenta afegã nos jornais brasileiros; porém, usava-se a palavra de origem árabe burca e não chadri, de origem persa. Nesse sentido, a tradução de chadri por burca na versão brasileira, a nosso ver, recorreria a um termo mais familiar no cenário cultural da tradução, o que corresponderia à expectativa do público e, por conseguinte, estaria mais em consonância com a representatividade da cultura afegã no contexto brasileiro ${ }^{7}$. Por outro lado, chama atenção a estratégia da tradutora em traduzir "ces longues robes des femmes afghanes"

7 No segundo volume da série, há novamente referência a essa peça de roupa em um diálogo entre a médica Juliette e Lefèvre. Nesse caso, a tradução brasileira apresenta "burca" como tradução de "chadri". 
por "essa única túnica comprida das mulheres afegãs", em que há o acréscimo do adjetivo "única", e a palavra "robes" é traduzida por "túnica". Ora, a opção pela palavra "túnica" recupera em parte o sentido de "robes" na medida em que uma túnica pode ser usada por homens e mulheres e, em geral, também possuem um comprimento amplo. Nesse sentido, "túnica" reproduz a intenção de traduzir o referente estrangeiro, isto é, aproximar o objeto estrangeiro ao contexto da cultura receptora, porém, ao adotar a palavra "túnica", novamente, há uma transformação daquilo que o "chadri" representa na cultura afegã e sua ligação com a prática religiosa, pois uma "túnica" pode ser usada por ambos os sexos, o que não ocorre com a peça de roupa afegã, que é de uso exclusivamente feminino. Evidentemente que um chadri ou burca não são túnicas, mas a tradução tenta dar uma noção ao leitor brasileiro sobre esse tipo de vestimenta. Além disso, vale notar que a função da roupa em seu contexto afegão também é desvirtuada na tradução, como era de se esperar, pois, conforme exposto na análise do trecho original, o narrador explica que o "chadri" será usado como disfarce pela equipe ao passar pela fronteira.

\section{Reflexões finais}

Conforme pudemos observar neste trabalho, a fotografia jornalística tem o poder de criar realidades por se constituir enquanto forma de expressão que pressupõe a ação do sujeito emissor e receptor para ser interpretada, logo, a fotografia jornalística é uma linguagem e, como tal, é parcial e arbitrária. Fica atestado, assim, o poder que a foto tem de criar uma visão sobre o Outro - ou uma verdade sobre o Outro - não só no contexto do jornal, mas também em outras formas de mídia que exploram esse recurso semiótico, como é o caso das histórias em quadrinhos, precisamente Le photographe. Devido ao fato de analisarmos essa obra na língua/cultura de partida e na língua/cultura de chegada, vimos que a construção de representações sobre o Outro se apresenta tanto no contexto original quanto na tradução, porém, essas representações podem se transformar no caminho da tradução, como vimos nos casos analisados nas Figuras 1 a 4.

Ainda no que se refere à questão do registro do real por meio da fotografia, o uso desse sistema de signo constitui, segundo Sontag (2003), um recurso retórico, já que a foto confere, tradicionalmente, legitimidade à narração dos fatos. Além disso, é a relação entre as fotos, os desenhos e o texto que constrói a progressão narrativa, assim, as cenas ficam compreensíveis para o leitor por meio da conjunção de duas linguagens: a linguagem quadrinística, pelo uso dos balões e quadros postos em sequência da esquerda para a direita, e da linguagem jornalística, que se configura nas imagens fotográficas e no relato do fotojornalista Didier Lefèvre que, além de ser personagem da narrativa gráfica, também é uma pessoa - um jornalista - que vivenciou os acontecimentos representados na cena.

A fim de elucidarmos nossa visão sobre a foto enquanto linguagem e, portanto, enquanto recurso expressivo que produz um efeito de real, mas não o real em si, vale citar a afırmação do filósofo Michel Foucault (1999, p. 15, grifos do autor): 
[...] a verdade a mais elevada já não residia mais no que era o discurso, ou no que ele fazia, mas residia no que ele dizia: chegou um dia em que a verdade se deslocou do ato ritualizado, eficaz e justo, de enunciação, para o próprio enunciado: para seu sentido, sua forma, seu objeto, sua relação a sua referência.

A partir da ideia exposta por Foucault (1999) acerca da verdade no enunciado, entendemos que o fato documentado pela fotografia e inserido em uma narrativa, seja ela uma narrativa exposta em um jornal ou em uma história em quadrinhos, concretizase por meio da linguagem que o veicula, dessa forma, a verdade, o fato, o mundo do Outro chega até nós somente pela linguagem que Outro sujeito constrói. Trata-se, em suma, de um ato tradutório primeiro, pois a realidade do Outro, o mundo do Outro, desloca-se da enunciação, do agora, para o seu enunciado, para o depois.

Por fim, ao verificarmos que a tradução e circulação de representações culturais formadas a partir da relação entre imagem e texto engendra pelo menos três ambivalências, a saber, a ambivalência da própria fotografia, que retrata apenas uma parte do real, mas que goza do status de evidência e verdade, conforme apontado por Susan Sontag (2003) e Boris Kossoy (2009), a ambivalência do sujeito no processo de tradução cultural que busca compreender o Outro por meio da diferenciação, frequentemente produzindo distorções e apropriações, como nos mostram os trabalhos de Bhabha (2006), e, por fim, a ambivalência do próprio tradutor, que busca fazer a ponte entre culturas distintas por meio da língua, o que implica escolhas que, muitas vezes, influenciam a construção de identidades culturais, conforme salienta Venuti (1998). Todas essas ambivalências podem ser vistas nas análises aqui apresentadas; dessa forma, concluímos este artigo lançando um desafio para a tradução: construir um novo discurso sobre o Outro que não reproduza aquele da língua/cultura de partida, o que constituiria uma nova noção de ética da/na tradução ou, ainda, questionar e refletir sobre o seu papel na construção de verdades parciais, distorções e identidades. Os estudos da tradução mostram que já estamos nesse caminho.

\section{REFERÊNCIAS}

ARAGÃO, S. M. O conhecimento do outro por meio da imagem e da tradução. 2018. Tese (Doutorado em Letras) - Faculdade de Filosofia, Letras e Ciências Humanas, Universidade de São Paulo, São Paulo, 2018.

AVELLAR, J. C. As folhas de contato e o fotojornalismo. Zum: revista de fotografia, Rio de Janeiro, Instituto Moreira Salles, 2015 [não paginado]. Disponível em: https://revistazum. com.br/radar/contatos-e-o-fotojornalismo/. Acesso em: 04 jan. 2019.

BAEZA GALLUR, P. Por una función crítica de la fotografía de prensa. Barcelona: Gustavo Gili, 2003. 
$\mathrm{BHABHA}, \mathrm{H}$. K. DissemiNation: time, narrative, and the margins of the modern nation. In: BHABHA, H. K. (org.). Nation and narration. London: Routledge, 2006. p. 291-322.

BHABHA, H. K. O local da cultura. Tradução Myriam Ávila, Eliana Lourenço de Lima Reis e Gláucia Renate Gonçalves. Belo Horizonte: Editora UFMG, 2013.

BUITONI, D. H. S. Fotografia e jornalismo: da prata ao pixel - discussões sobre o real. In: COELHO, C. N. P.; KÜNSCH, D. A.; MENEZES, J. E. de O. (org.). Estudos de comunicação contemporânea: perspectivas e trajetórias. São Paulo: Plêiade, 2012. p. 143-158.

CHARTIER, R. O mundo como representação. Tradução Andréa Daher e Zenir Campos Reis. Estudos avançados, v. 11, n. 5, p. 173-191, 1991.

EISNER, W. Quadrinhos e arte sequencial. São Paulo: Martins Fontes, 1999.

FOUCAULT, M. A ordem do discurso: aula inaugural no Collège de France pronunciada em 2 de dezembro de 1970. Tradução Laura F. de A. Sampaio. São Paulo: Loyola, 1999.

GUIBERT, E. Préface. In: GUIBERT, E.; LEFÈVRE, D.; LEMERCIER, F. Conversations avec le photographe. Marcinelle: Dupuis, 2009. p. 14-20.

GUIBERT, E.; LEFÈVRE, D.; LEMERCIER, F. Le Photographe. Tome 1. Marcinelle: Dupuis, 2003.

GUIBERT, E.; LEFÈVRE, D.; LEMERCIER, F. O fotógrafo. v. 1. Tradução Dorotée de Bruchard. São Paulo: Conrad Editora do Brasil, 2010.

GUIBERT, E.; LEFÈVRE, D.; LEMERCIER, F. Le Photographe. Tome 3. Marcinelle: Dupuis, 2006.

GUIBERT, E.; LEFÈVRE, D.; LEMERCIER, F. O fotógrafo. v. 3. Tradução Dorotée de Bruchard. São Paulo: Conrad Editora do Brasil, 2010.

KOCH, I. G. V. Introdução à linguística textual: trajetória e grandes temas. São Paulo: Martins Fontes, 2004.

KOSSOY, B. Realidades e ficções na trama fotográfica. São Paulo: Ateliê Editorial, 2009. 
NEVEU, E. Sociologia do jornalismo. Tradução Joaquim Fidalgo e Manuel Pinto. Porto: Porto Editora, 2005.

PYM, A. Exploring translation theories. New York: Routledge, 2010.

RAMOS, P.; CHINEN, N. (org.). Enquadrando o real: ensaios sobre quadrinhos (auto) biográficos, históricos e jornalísticos. São Paulo: Criativo, 2016. p. 197-229.

SONTAG, S. Diante da dor dos outros. Tradução Rubens Figueiredo. São Paulo: Companhia das Letras, 2003.

VENUTI, L. The scandals of translation: towards an ethics of difference. London: Routledge, 1998. 